\title{
Daptomycin and tigecycline susceptibility of vancomycin resistant enterococci isolated from rectal swab cultures
}

\author{
Şerife Altun ${ }^{1}$, Hatice Uludağ Altun², Çiğdem Ataman Hatipoğlu ${ }^{3}$, Cemal Bulut ${ }^{3}$, Sami Kinikli³, \\ Ali Pekcan Demiröz ${ }^{3}$ \\ ${ }^{1}$ Sarıkamış State Hospital, Infectious Diseases \& Clinical Microbiology Department, Kars Turkey \\ ${ }^{2}$ Turgut Özal University Clinical Microbiology Department, Ankara Turkey \\ ${ }^{3}$ Ankara Training $\mathcal{E}$ Research Hospital, Infectious Diseases E Clinical Microbiology Department, Ankara Turkey
}

\begin{abstract}
Objective: Vancomycin resistant enterococci (VRE) are important healthcare associated multidrug resistant organisms because of their easily spread in the hospital environment, difficulty to cure and high mortality rate. The aim of this study was to evaluate in vitro activity of daptomycin and tigecycline against VRE strains isolated from rectal swab samples of hospitalized patients.
\end{abstract}

Methods: Sixty non-duplicate VRE strains isolated from rectal swabs of hospitalized patients between October 2010 and February 2013 at Ankara Training and Research Hospital were included into the study. Ankara Training and Research Hospital in Ankara in Turkey is a 600-bed, tertiary care, teaching hospital. Minimum inhibitory concentration (MIC) values of daptomycin and tigecycline were determined by E-test method (bioMerieux, France).

Results: All of the strains were susceptible to daptomycin, three of them (5\%) were resistant to tigecycline. $\mathrm{MIC}_{50}$ and $\mathrm{MIC}_{90}$ values of daptomycin were $1.5 \mu \mathrm{g} / \mathrm{ml}$ and $2 \mu \mathrm{gr} / \mathrm{ml}$, and of tigecycline were $0.64 \mu \mathrm{g} / \mathrm{ml}$ and $0.125 \mu \mathrm{g} / \mathrm{ml}, \mathrm{respec}-$ tively.

Conclusion: As a result; all of the strains were susceptible to daptomycin. On the other hand, resistance to tigecycline was exhibited by $5 \%$ of VRE isolates. Clinicians should be aware of the possibility of the emergence of tigecycline nonsusceptibility and should closely monitor tigecycline MICs of enterococci. J Microbiol Infect Dis 2014; 4(3): 107-110

Key words: VRE, daptomycin, tigecycline, susceptibility

\section{Rektal sürüntü kültürlerinden izole edilen vankomisin dirençli enterokok suşlarının daptomisin ve tigesiklin duyarlılıkları}

\section{ÖZET}

Amaç: Hastane ortamında kolay yayılımı, infeksiyonlarının tedavisinin zor ve mortalite oranlarının yüksek olması nedeni ile çoklu ilaca dirençli vankomisin dirençli enterokoklar (VRE) önemli organizmalardır. Bu çalışmanın amacı; yatan hastalardan alınan rektal sürüntü örneklerinden izole edilen VRE suşlarında in vitro daptomisin ve tigesiklin duyarlılı̆ını belirlemektir.

Yöntemler: Çalışmaya Ekim 2010- Şubat 2013 tarihleri arasında Ankara Eğitim ve Araştırma Hastanesinde yatan hastaların rektal sürüntülerinden izole edilen 60 VRE suşu dahil edildi. Ankara Eğitim ve Araştırma hastanesi 600 yataklı 3. basamak bir araştırma hastanesidir. Daptomisin ve tigesiklin için minimum inhibitor konsantrasyon (MIK) değerleri E-test yöntemi (bioMerieux, Fransa) ile belirlendi.

Bulgular: Tüm suşlar daptomisine duyarlı olup; üçü (\%5) tigesikline dirençli saptandı. Daptomisin için MIK50 ve MIK90 değerleri sırasıyla $1.5 \mu \mathrm{gr} / \mathrm{ml}$ ve $2 \mu \mathrm{gr} / \mathrm{ml}$ saptanırken tigesiklin için $0.064 \mu \mathrm{g} / \mathrm{ml}$ ve $0.125 \mu \mathrm{g} / \mathrm{ml}$ olarak saptandı.

Sonuç: Sonuç olarak; tüm suşlar daptomisine duyarlı saptandı. Diğer yandan VRE izolatlarında tigesiklin direnci \%5 olarak saptandı. Klinisyenler enterokoklarda tigesiklin direncine karşı dikkatli olmalı ve tigesiklin MıK değerini yakından takip etmelidir.

Anahtar kelimeler: VRE, daptomisin, tigesiklin, duyarlılık 


\section{INTRODUCTION}

Antimicrobial drug resistance is a growing public health problem, and multidrug-resistant pathogens such as vancomycin resistant enterococci (VRE) are increasing worldwide, with the increased consumption of glycopeptides. The limited therapeutic options currently available for the treatment of VRE infections emphasize the need for new antimicrobial agents with activity against these pathogens and for ongoing efforts to limit the transmission of VRE in health care settings. ${ }^{1,2}$ The clinical importance of the genus Enterococcus is directly related to its antibiotic resistance, which contributes to the risk of colonization and infection. ${ }^{3}$ However, colonizations are far more frequent than infections. ${ }^{4}$ Daptomycin and tigecycline are effective in the treatment of infections related to gram positive bacteria. 5,6 Daptomycin, a cyclic lipopeptide produced by Streptomyces roseosporus, approved for the treatment of complicated skin and soft-tissue infections and Staphylococcus aureus bloodstream infection, is the only antibiotic with in vitro bactericidal activity against VRE that is approved by the Food and Drug Administration (FDA). ${ }^{7}$ Daptomycin exhibits a lower potency against enterococci than staphylococci. ${ }^{8,9}$ Tigecycline, the first member of a new class of broad-spectrum antibiotics, the glycylcyclines was licensed for the parenteral treatment of adult patients with complicated intra-abdominal infections and complicated skin and soft tissue infections. ${ }^{10}$ Tigecycline is highly active against Gram-positive pathogens, including methicillin resistant $S$. aureus (MRSA), methicillin resistant $S$. epidermidis (MRSE) and vancomycin susceptible and resistant enterococci. ${ }^{11,12}$ The aim of this study was to evaluate the in vitro activity of daptomycin and tigecycline against VRE isolates.

\section{METHODS}

This study performed at a 600 bed tertiary care hospital which has an infection control commitee. In the period from October 2010 to February 2013, 60 non-duplicated vancomycin resistant Enterococcus faecalis and Enterococcus faecium strains were isolated from rectal swab cultures from patients intensive care units and various clinics in our hospital. The isolates were stored at $-20^{\circ} \mathrm{C}$ in brain heart infusion broth, suplemented with glycerol, before testing. The isolates were grown overnight on sheep blood agar at $37^{\circ} \mathrm{C}$ for $24 \mathrm{~h}$ and were tested for ampicillin, erithromycin, vancomycin, teicoplanin and linezolid. Suspension of the isolates in $0.5 \mathrm{Mc}$ -
Farland was prepared and inoculated on to Mueller Hinton agar plates. The testing of the antimicrobial susceptibilities to the ampicillin, erythromycin, vancomycin, teicoplanin and linezolid were carried out on Mueller Hinton agar by the Kirby Bauer disc diffusion method. Susceptibilities of the strains to daptomycin and tigecycline were performed using the E-test (bioMerieux, France) according to the recommendations of the CLSI 2011 and the manufacturer. The MIC breakpoints used for susceptibility for daptomycin and tigecycline were taken as $\leq 4$ $\mu \mathrm{g} / \mathrm{ml}$ and $\leq 0.5 \mu \mathrm{g} / \mathrm{ml}$, respectively, as approved by the FDA. ${ }^{8,13}$ E. faecalis ATCC 29212 was used as a control strain in the study.

\section{RESULTS}

Among 60 enterococcal isolates, 22 (36.7\%), 28 $(46.7 \%), 1(1.7 \%)$ and $9(15.0 \%)$ were isolated in 2010, 2011, 2012 and 2013, respectively. Thirty eight strains $(63.0 \%)$ were isolated from intensive care units and $22(37 \%)$ from internal medicine clinics (Figure 1). All of the strains were resistant to ampicillin, erythromycin, vancomycin, teicoplanin but susceptible to linezolid. Daptomycin MIC values of strains were determined between 0.125 and $4 \mu \mathrm{gr} /$ $\mathrm{ml}$; all of them were susceptible. $\mathrm{MIC}_{50}$ and $\mathrm{MIC}_{90}$ values of daptomycin was $1.5 \mu \mathrm{gr} / \mathrm{ml}$ and $2 \mu \mathrm{gr} / \mathrm{ml}$, respectively. Tigecycline MIC values of the strains were determined between 0.023 and $0.75 \mu \mathrm{g} / \mathrm{ml} ; 3$ of the strains having MIC $\geq 0,5 \mu \mathrm{g} / \mathrm{ml}$ were resistant to tigecycline. $\mathrm{MIC}_{50}$ and $\mathrm{MIC}_{90}$ values of tigecycline were $0.064 \mu \mathrm{g} / \mathrm{ml}$ and $0.125 \mu \mathrm{g} / \mathrm{ml}$, respectively (Table 1).

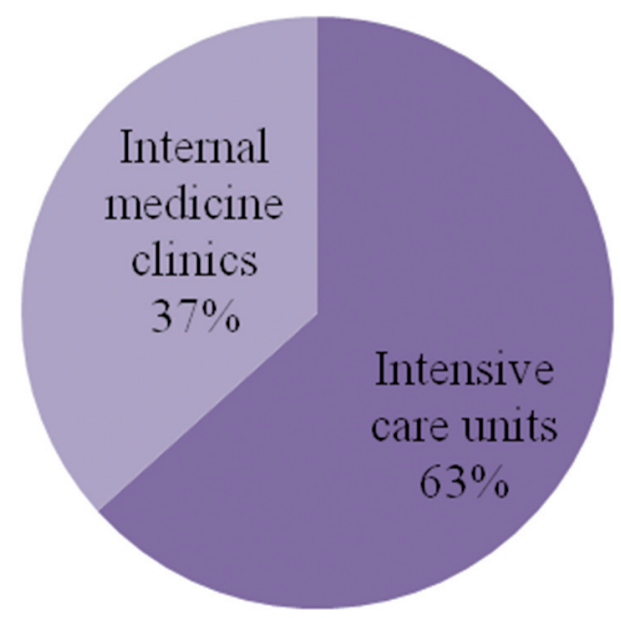

Figure 1. Distribution of rectal swab samples to clinics 
Table 1. $\mathrm{MIC}_{50}$ and $\mathrm{MIC}_{90}(\mu \mathrm{g} / \mathrm{mL})$ values for daptomycin and tigecycline of VRE strains.

\begin{tabular}{lcccc}
\hline MIC $(\mu \mathrm{g} / \mathrm{mL})$ & & & & \\
\hline & MIC $_{50}$ & MIC $_{90}$ & MIC Range & Susceptibility \% \\
Daptomycin & 1,5 & 2 & $0,125-3$ & $100 \%$ \\
Tigecycline & 0,064 & 0,125 & $0,023-0,75$ & $95 \%$ \\
\hline
\end{tabular}

MIC: Minimum inhibitory concentration, VRE: Vancomycin resistant enterococ

\section{DISCUSSION}

Vancomycin had been used since 1950s, but the emergence of resistance of Enterococcus species was not reported until 1988 in the United Kingdom and France. Incremental vancomycin usage for MRSA infection may explain the timing. ${ }^{14}$ Since VRE was first isolated in Turkey from nosocomial infection in 1998 at Akdeniz University Hospital, the incidence of antimicrobial-resistant bacteria has continuously increased with the rising consumption of antibiotics. ${ }^{15}$

Daptomycin, a new lipopeptide antibiotic, is highly bactericidal against the majority of gram-positive human pathogens, including MRSA and VRE. Its mechanism of action is unique resulting in the destruction of the membrane potential without lysis of the cell wall. ${ }^{16}$ Tigecycline, the first semisynthetic glycylcycline available for clinical application, is a novel 9-t-butyl-substituted minocycline derivative that overcomes several major tetracycline resistance mechanisms. It demonstrates broad-spectrum antimicrobial effects against multiple resistant gram-positive, gram-negative, anaerobic, and atypical pathogens. ${ }^{17}$ Sader et al. ${ }^{18}$ evaluated the in vitro activity of daptomycin and comparators tested against clinical isolates from European hospitals over a 7-year period (2003-2009); 7241 consecutive Enterococcus spp. (9.4\% VRE) isolates were collected in 34 medical centers located in $13 \mathrm{Eu}$ ropean countries, Turkey and Israel. All E. faecalis strains were susceptible to daptomycin $\left(\mathrm{MIC}_{50}\right.$ : $2 \mu \mathrm{g} / \mathrm{ml}, \mathrm{MIC}_{90}: 2 \mu \mathrm{g} / \mathrm{ml}, 100 \%$ susceptible). In this study, daptomycin and linezolid were the most active agents tested against VRE. Aktaş et al.19 evaluated the in vitro activity of daptomycin against 118 VRE strains by broth dilution method and all of the strains susceptible to daptomycin $\left(\mathrm{MIC}_{50}: 1 \mu \mathrm{g} / \mathrm{ml}\right.$, $\mathrm{MIC}_{90}: 2 \mu \mathrm{g} / \mathrm{ml}$ ) and MIC range was $0.125-2 \mu \mathrm{g} / \mathrm{ml}$. At a tertiary care hospital in Turkey, all 31 enterococcal strains, 4 of which were VRE, were found to be susceptible to daptomycin by E-test method and MIC range was $0.094-2 \mu \mathrm{g} / \mathrm{ml} .^{20} \mathrm{In}$ another study in a tertiary care hospital in Turkey, all 52 enterococcal strains in which resistance to vancomycin were not investigated, were found to be susceptible to daptomycin. ${ }^{21}$ Similar to these results, in our study, all of 60 VRE strains were susceptible to daptomycin; $\mathrm{MIC}_{50}$ was $1.5 \mu \mathrm{g} / \mathrm{ml}, \mathrm{MIC}_{90} 2 \mu \mathrm{g} / \mathrm{ml}$. Chitnis et al.22 evaluated 50 VRE strains, 20 were from clinical samples and 30 were from rectal swabs from newborns in Central Indian hospital. All of them were susceptible to daptomycin. Among these VRE isolates, MIC for daptomycin was $0.19-1.5 \mu \mathrm{g} / \mathrm{ml}$ except two isolates which had MIC of $3 \mu \mathrm{g} / \mathrm{ml}$. Nonsusceptibility of enterococci to daptomycin (MIC>4 $\mu \mathrm{g} / \mathrm{ml}$ by broth dilution and E-test) remains infrequent, with an overall prevalence of $0.6 \%$ among clinical isolates in a recent series. ${ }^{7}$ It is declared that the resistance of daptomycin in E. faecium is between $0.5 \%$ and $1.5 \%$ worldwide. ${ }^{23}$ Kamboj et al. ${ }^{24}$ examined the daptomycin susceptibility profile of all isolates collected during episodes of VRE bacteremia at a cancer center in New York between 20072009. One hundred seventy six patients had VRE bacteremia, including 18 (10.2\%) with bacteremia due to daptomycin resistant VRE strains; resistance rates were increased significantly, from $3.4 \%$ in 2007 to $15.2 \%$ in 2009.

Sader et al..$^{25}$ monitored the in vitro activity of tigecycline in 2011 for continued potency worldwide. A total of 22.005 gram positive and gram negative isolates were consecutively collected in North America, Europe, Latin America and Asia Pacific Region and tested for susceptibility according to the broth microdilution method. Of the VRE isolates $99 \%$ were susceptible to tigecycline. Jones et al. ${ }^{26}$ studied resistance patterns of 218 Latin American enterococcal isolates. VRE rate was $14 \%$ but all of them were susceptible to tigecycline and daptomycin. Chen et al. ${ }^{27}$ evaluated in vitro activity of tigecycline to 219 vancomycin resistant $E$. faecium isolates collected during the period from 2006 to 2010. Among these strains $98.6 \%$ were susceptible to tigecycline $\left(\mathrm{MIC}_{50}: 0.03 \mu \mathrm{g} / \mathrm{ml}, \mathrm{MIC}_{90}: 0.125 \mu \mathrm{g} /\right.$ $\mathrm{ml}$ ) and MIC range was $0.016-1 \mu \mathrm{g} / \mathrm{ml}$. Karaoğlan et al. ${ }^{28}$ monitored in vitro activity of tigecycline in 60 enterococcal strains from Turkey (57 E. faecium and 3 E. gallinorum) by E-test method; all of them susceptible to tigecycline $\left(\mathrm{MIC}_{50}: 0.125 \mu \mathrm{g} / \mathrm{ml}, \mathrm{MIC}_{90}\right.$ : $0.5 \mu \mathrm{g} / \mathrm{ml}$ ) and MIC range was $0.094-1 \mu \mathrm{g} / \mathrm{ml}$. Of our 60 VRE isolates, three of them $(5 \%)$ were resistant to tigecycline. Our resistant rate to tigecycline was higher than the other studies. The limitatiton of our study is that the subtyping was not performed. It would be better if we could have identified E. spe- 
cies as $E$. faecium or $E$. faecalis. It is known that $E$. faecium isolates are more resistant than $E$. faecalis isolates. $^{4}$

\section{Conclusion}

As a conclusion; all of the strains were susceptible to daptomycin, so this agent can be used at the treatment of VRE. Resistance to tigecycline was exhibited by $5 \%$ of VRE isolates. We think that clinicians should be aware of the possibility of the emergence of tigecycline nonsusceptibility and should closely monitor tigecycline MICs of enterococcal strains.

Acknowledgement: This study was presented as a poster in Turkey EKMUD 2013 Congress

\section{REFERENCES}

1. Eliopoulos GM. Microbiology of drugs for treating multiply drugresistant gram-positive bacteria. J Infect 2009;59:17-24.

2. Diekema DJ, Jones RN. Oxazolidinone antibiotics. Lancet 2001;358:1975-1982.

3. Klare I, Witte W, Wendt C, Werner G. Vancomycin-Resistant Enterococci (VRE). Recent results and trends in development of antibiotic resistance. Bundesgesunddheitsblatt Gesundheitsforschung Gesundheitssschutz 2012;55:13871400.

4. Kristich CJ, Rice LB, Arias CA. Enterococcal Infection-Treatment and Antibiotic Resistance. In: Gilmore MS, Clewell DB, Ike Y, Shankar N, eds. Enterococci: From Commensals to Leading Causes of Drug Resistant İnfection (Internet) Boston: Massachusetts Eye and Ear Infirmary 2014.

5. Entenza JM, Moreillon P. Tigecycline in combination with other antimicrobials: a review of in vitro, animal and case report studies. Int J Antimicrob Agents 2009;34:8.

6. Steenbergen JN, Mohr JF, Thorne GM. Effects of daptomycin incombination with other antimicrobial agents: a review of in vitro and animal model studies. J Antimicrob Chemother 2009;64:1130-1138.

7. Kelesidis T, Humphries R, Uslan DZ, Pegues DA. Daptomycin nonsusceptible enterococci: an emerging challenge for clinicians. Clin Infect Dis 2011;52:228-234.

8. Clinical and Laboratory Standards Institute. 2011. Performance standards for antimicrobial susceptibility testing; twenty-first informational supplement, CLSI document M100-S21. Clinical and Laboratory Standards Institute, Wayne, PA.

9. Sader HS, Jones RN. Antimicrobial susceptibility of Grampositive bacteria isolated from US medical centers: results of the Daptomycin Surveillance Program (2007-2008). Diagn Microbiol Infect Dis 2009;65:158-162.

10. Brink AJ, Bizos D, Boffard KD, et al. Guideline: Appropriate use of tigecycline. S Afr Med J 2010;100:388-394.

11. Hoban DJ, Bouchillon SK, Johnson BM, et al. Tigecycline Evaluation and Surveillance Trial (TEST program) Group. Invitro activity of tigecycline against 6792 Gram-Negative and Gram-positive clinical isolates from the global Tigecycline Evaluation and Surveillance Trial (TEST program 2004). Diagn Microbiol Infect Dis 2005;52:215-217.
12. Reinert RR, Low DE, Rossi F, et al. Antimicrobial susceptibility among organisms from Asia/Pasific Rim, Europe and Latin and North America collected as part of TEST and the in vitro activity of tigecycline. J Antimicrob Chemother 2007;60:1018-1029.

13. Wyeth Pharmaceuticals. Tygacil (tigecycline) for injection (Package Insert). 2005. Wyeth Pharmaceuticals Inc., Philadelphia, PA.

14. Leclerq R, Courvalin P. Resistance to glycopeptides in Enterococci. Clin Infect Dis 1997; 24:545-554.

15. Akıncı E, Balık I, Tekeli E. Antimirobial susceptibility of Enterococcus species collected from clincal specimens. Flora 1999;4:4045.

16. Cottagnoud P. Daptomycin: A new treatment for insidious infections due to gram-positive pathogens. Swess Med Wkly 2008;138:93-99.

17. Cai $Y$, Wang R, Liang B, et al. Systematic review and metaanalysis of the effectiveness and safety of tigecycline for treatment of infectious disease. Antimicrob Agents Chemother 2011;55:1162-1172.

18. Sader HS, Farrell DJ, Jones RN. Antimicrobial activity of daptomycin tested against gram-positive strains collected in European hospitals: results from 7 years of resistance surveillance (2003-2009). J Chemother 2011;23:200-206.

19. Aktaş G, Derbentli Ş. In vitro activity of daptomycin against VRE and MRSA strains. Mikrobiyol Bul 2014;48:123-128.

20. Şamlıoğlu P, Ece G, Atalay S, Köse Ş. Daptomycin susceptibility in gram positive cocci isolated from intensive care units. ANKEM Derg 2011;25:173-177.

21. Ertem GT, Öztürk B, Hatipoğlu ÇA et al. In vitro susceptibilities of Staphylococcus and E. species isolates to linezolid daptomycin, teicoplanin and fucidic acid. Turkiye Klinikleri J Med Sci 2012;33:1381-1387.

22. Chitnis S, Katara G, Hemvani N, et al. In vitro activity of daptomycin \& linezolid against methicillin resistant Staphylococcus aureus \& vancomycin resistant enterococci isolated from hospitalized cases in Central India. Indian J Med Res 2013;137:191-196.

23. Canton R, Ruiz-Garbajosa P, Chaves RL, Johnsn AP. A potential role for daptomycin in enterococcal infections: what is the evidence? J Antimicrob Chemother 2010;65:1126-1136.

24. Kamboj M, Cohen N, Gilhuley K, Babady NE, Seo SK, Sepkowitz KA. Emergence of daptomycin-resistant VRE: Experience of a single institution. Infect Control Hosp Epidemiol 2011:32;391-394.

25. Sader HS, Flamm RK, Jones RN. Tigecycline activity tested against antimicrobial resistant surveillance subsets of clinical bacteria collected worldwide. Diagn Microbiol Infect Dis 2011:76:217-221.

26. Jones RN, Guzman-Blanco M, Gales AC, et al. Susceptibility rates in Latin American nations: report from a regional resistance surveillance program (2011). Braz J Infect Dis. 2013 :17:672-681.

27. Chen YH, Lu PL, Huang CH, et al. Trends in susceptibility of clinically important resistant bacteria to tigecycline: results from the tigecycline in vitro surveillance in Taiwan study, 2006 to 2010. Antimicrob Agents Chemother 2012;53:14521457.

28. Karaoğlan İ, Zer Y, Namıduru M. In vitro activity of tigecycline for Vancomycin-resistant E. species Strains. ANKEM Derg 2008;22:153-155. 